\title{
Patterns and drivers of megabenthic secondary production on the Barents Sea shelf
}

\author{
Renate Degen $^{1, *}$, Lis Lindal Jørgensen ${ }^{2}$, Pavel Ljubin ${ }^{3}$, Ingrid H. Ellingsen ${ }^{4}$, \\ Hendrik Pehlke ${ }^{1}$, Thomas Brey ${ }^{1}$
}

\author{
${ }^{1}$ Alfred Wegener Institute Helmholtz Centre for Polar and Marine Research, Am Handelshafen 12, 27570 Bremerhaven, Germany \\ ${ }^{2}$ Institute of Marine Research, 9294 Tromsø, Norway \\ ${ }^{3}$ Polar Research Institute of Marine Fisheries and Oceanography, 183038 Murmansk, Russia \\ ${ }^{4}$ SINTEF Fisheries and Aquaculture, Brattørkaia 17C, 7010 Trondheim, Norway
}

ABSTRACT: Megabenthos plays a major role in the overall energy flow on Arctic shelves, but information on megabenthic secondary production on large spatial scales is scarce. Here, we estimated for the first time megabenthic secondary production for the entire Barents Sea shelf by applying a species-based empirical model to an extensive dataset from the joint Norwegian-Russian ecosystem survey. Spatial patterns and relationships were analyzed within a GIS. The environmental drivers behind the observed production pattern were identified by applying an ordinary least squares regression model. Geographically weighted regression (GWR) was used to examine the varying relationship of secondary production and the environment on a shelfwide scale. Significantly higher megabenthic secondary production was found in the northeastern, seasonally ice-covered regions of the Barents Sea than in the permanently ice-free southwest. The environmental parameters that significantly relate to the observed pattern are bottom temperature and salinity, sea ice cover, new primary production, trawling pressure, and bottom current speed. The GWR proved to be a versatile tool for analyzing the regionally varying relationships of benthic secondary production and its environmental drivers $\left(\mathrm{R}^{2}=0.73\right)$. The observed pattern indicates tight pelagic-benthic coupling in the realm of the productive marginal ice zone. Ongoing decrease of winter sea ice extent and the associated poleward movement of the seasonal ice edge point towards a distinct decline of benthic secondary production in the northeastern Barents Sea in the future.

KEY WORDS: Arctic $\cdot$ Benthos $\cdot$ Megafauna $\cdot$ Pelagicbenthic coupling · Geographically weighted regression GWR $\cdot$ Geostatistics

\footnotetext{
${ }^{*}$ Corresponding author: renate.degen@hotmail.com
}

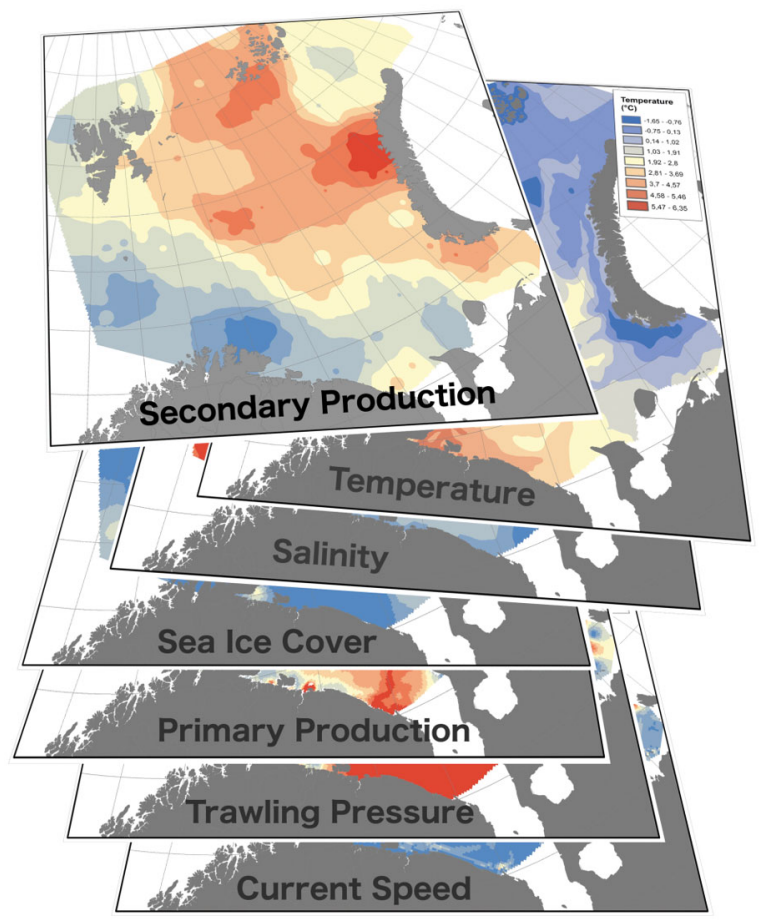

Six environmental parameters significantly relate to the observed pattern of high megabenthic secondary production in the northeastern Barents Sea.

Image: $R$ Degen

\section{INTRODUCTION}

Benthic secondary production constitutes an important pathway of energy flow on Arctic shelves (Piepenburg et al. 1995). Accordingly, it is of particular ecological and economical interest to estimate secondary production in the Barents Sea, which holds

() The authors 2016. Open Access under Creative Commons by Attribution Licence. Use, distribution and reproduction are unrestricted. Authors and original publication must be credited. 
one of the world oceans' richest fisheries (Wassmann et al. 2006b). The Barents Sea ecosystem is characterized by the interplay of polar and Atlantic water masses, and by a seasonal ice cover (Ingvaldsen \& Loeng 2009). However, the ongoing rapid retreat of sea ice raises questions concerning the current and future productivity of the area. The joint Norwegian-Russian Ecosystem Survey (Michalsen et al. 2013) produced an extensive dataset on megabenthos that covers the entire Barents Sea. This dataset is unique in spatial coverage and resolution and thus allows us, for the first time, to model megabenthic secondary production for an entire Arctic shelf.

Macrozoobenthos (i.e. size class of animals $<1-2 \mathrm{~cm}$, usually sampled with grabs or box cores) of Arctic shelves and the Barents Sea in particular has been studied extensively in recent decades (Cochrane et al. 2009 and references therein). It is a significant player in benthic carbon cycling and serves as food for a variety of higher trophic level and commercially important species like cod or halibut (Clough et al. 2005, Renaud et al. 2007). Significantly less information is available on benthic megafauna (animals of a size visible on photos or caught via bottom trawling) of Arctic shelves (Bluhm et al. 2009, Roy et al. 2014, Grebmeier et al. 2015b, Jørgensen et al. 2015), although it represents an important compartment of benthic energy flow (Piepenburg et al. 1995). Moreover, little is known about Barents Sea benthic secondary production of either mega- or macrobenthos, i.e. the newly formed biomass per unit of area and time, despite the general awareness of the benthic compartment's role in energy flow and food webs (Piepenburg et al. 1995, Cochrane et al. 2009). To date, only 1 study (Kędra et al. 2013) has dealt with benthic community secondary production, compared to some available literature on single benthic species production (e.g. Bluhm et al. 1998) and the numerous publications on primary production and pelagic secondary production (Sakshaug et al. 2009, Dalpadado et al. 2014). Kedra et al. (2013) estimated benthic infauna and epifauna secondary production on the Spitsbergen Bank to amount to $\sim 2$ and $\sim 22 \mathrm{~g} \mathrm{C} \mathrm{m}^{-2}$ $\mathrm{yr}^{-1}$, respectively. No information is currently available from the Barents Sea region on the megabenthic community production to biomass (P:B) ratios, which represent the rate of biomass turnover (Benke 2012).

The first systematic large-scale study on Barents Sea megafauna results from the joint NorwegianRussian Ecosystem Survey (Michalsen et al. 2013) and was published recently (Anisimova et al. 2010, Jørgensen et al. 2015). Jørgensen et al. (2015) provided the first explicit, large-scale analysis of Barents
Sea megafauna community composition and distribution patterns and identified a northern and a southern megafauna assemblage which can be divided further into 2 subregions each. The subregions are characterized by the environmental parameters water depth, temperature, salinity, and the number of ice-days by means of a canonical correspondence analysis. The border between these assemblages coincides with the encounter of colder Arctic $\left(<0^{\circ} \mathrm{C}\right)$ and warmer Atlantic $\left(>3^{\circ} \mathrm{C}\right)$ bottom water, hence, it is termed the 'Benthic Polar Front' (see Fig. 1) (Jørgensen et al. 2015). This front runs slightly differently than the oceanic Polar Front, which is shaped by surface water masses (Fig. 1) (Loeng et al. 1997). The northern megafauna assemblage has more taxa, higher abundance, and higher biomass than the southern assemblage (Jørgensen et al. 2015). In the north, benthic biomass is dominated by echinoderms, followed by Crustacea and Porifera. The southern assemblage can be further separated in a south-western section where Porifera dominate, followed by Echinodermata, and a south-eastern section where benthic biomass is more evenly shared among Echinodermata, Mollusca, and Porifera.

Generally food input is seen as the main driver of benthic fauna distribution and biomass at large regional scales, while seabed attributes explain patterns more significantly at local scales (Pearson \& Rosenberg 1978, Piepenburg 2005, Carroll et al. 2008). Arctic shelf communities reflect the primary production regime of the overlying water column in terms of biomass, abundance, and production, suggesting a tight pelagic-benthic coupling (Tamelander et al. 2006, Grebmeier et al. 2006, 2015a). This also holds true for the Barents Sea macrofauna, which shows the highest biomass on the shallow Spitsbergen and Central Banks, the Novaya Zemlya Bank, and the Pechora Sea (Cochrane et al. 2009), i.e. areas that have high values in models of primary productivity (Wassmann et al. 2006b). Zenkevitch (1963) pointed out that in the Barents Sea the highest benthic biomass along the Polar Front correlates inversely with water temperature, and presumed that this relates to the fact that areas with the coolest bottom water coincide with areas of the most active mixing and subsequent upwelling. In the Polar Front area, less saline Arctic water overlies dense and nutrient-rich Atlantic waters. Turbulent gyres provoke mixing of the different water masses, and iceedge upwelling of nutrients may occur (Loeng et al. 1997, Slagstad et al. 1999, Denisenko 2002, Mundy et al. 2009). Especially in shallower areas like Spitsbergen and the Central Bank, wind and tidal forcing are 
other sources of enhanced vertical mixing (Slagstad \& McClimans 2005, Sundfjord et al. 2008). The intense ice-edge bloom with associated high biomass in combination with turbulent mixing can promote extensive vertical export of high quality particulate organic matter (POM; Reigstad et al. 2008). However, Arctic studies that link benthic production patterns to ecosystem processes on large spatial scales are scarce (e.g. Highsmith \& Coyle 1990), and this is even more the case for benthic megafauna. Likewise, little attention has been given to regional patterns of megafauna production on the Barents Sea shelf, but exactly this information is needed to develop reliable energy flux models (e.g. Dommasnes et al. 2001) and future scenarios for this rapidly changing ecosystem.

Here, we analyzed for the first time megabenthic community production for an entire Arctic shelf, i.e. the Barents Sea. We estimated secondary production by means of a species-based empirical model (Brey 2012) and used a global regression model to identify significant drivers of the observed production pattern. Owing to the substantial regional variations of environmental conditions (water depth, temperature, salinity, sediment structure, and sea-ice concentration) and human impact (commercial trawling), we applied a geographically weighted regression (GWR) model to examine the relationship of secondary production with the environment in space (Fotheringham et al. 2002). To our knowledge, this is the first time such geo-statistical techniques have been used to map and spatially analyze marine benthic secondary production.

We aimed to (1) estimate total and major group secondary production (P) of megafauna for the entire Barents Sea shelf, (2) identify regional patterns, (3) identify the significant environmental drivers behind the observed patterns, and (4) analyze their regionally varying relationship to $P$.

\section{MATERIALS AND METHODS}

\section{Study area}

The Barents Sea is the deepest of all circum-Arctic shelf seas with depths down to $500 \mathrm{~m}$ in the western troughs (Jakobsson et al. 2004). Generally, the bathymetry is characterized by several shallow shelf banks that are segregated by a complex pattern of deeper depressions $(>200 \mathrm{~m})$, and the average depth is $230 \mathrm{~m}$ (Zenkevitch 1963, Piepenburg et al. 1995, Ingvaldsen \& Loeng 2009). The Barents Sea covers an area of 1.6 million $\mathrm{km}^{2}$ and is surrounded by the
Arctic Ocean in the north, the island Novaya Zemlya in the east, the Norwegian and Russian mainland in the south, and the Norwegian Sea and Fram Strait in the west (Ozhigin et al. 2011) (Fig. 1). Three main water masses characterize the Barents Sea (Fig. 1): nutrient-rich Atlantic water with temperatures $>3^{\circ} \mathrm{C}$ and salinity of $>35$ and coastal water with temperatures in a wider range and salinity $<34.7$ enter the Barents Sea in the southwest, and Arctic water with temperatures $<0^{\circ} \mathrm{C}$ (core temp. $<-1.5$ ) and salinity of 34.4-34.7 enters the shelf between Svalbard and Franz Josef Land, between Franz Josef Land and Novaya Zemlya, and via a small inflow from the Kara Sea south of Novaya Zemlya (Ingvaldsen \& Loeng 2009). A Polar Front (grey line in Fig. 1) separates the warm Atlantic water from the cold Arctic water, and thus the permanently ice-free areas in the southwest from the seasonally ice-covered northeastern areas (Loeng et al. 1997). Regarding bottom temperature, the front runs slightly differently and is termed the 'Benthic Polar Front,' separating a northern from a southern faunal assemblage (Jørgensen et al. 2015) (dashed grey line in Fig. 1). Sediment structure on the shelf is heterogeneous; fine mud dominates deeper areas, and coarser substrates are found in shallower areas with stronger currents (Jørgensen et al. 2015). Current speed on the Barents shelf is moderate, with highest values of $>0.25 \mathrm{~m} \mathrm{~s}^{-1}$ in the Norwegian Coastal Current, but just ca. $0.1 \mathrm{~m} \mathrm{~s}^{-1}$ in the western outflow (Ingvaldsen \& Loeng 2009). Pelagic primary production is highest in the southwestern regions influenced by nutrient-rich Atlantic water, with values $>100 \mathrm{~g} \mathrm{C} \mathrm{m}^{-2} \mathrm{yr}^{-1}$, and is thought to be lowest in the seasonally ice-covered northeast (Wassmann et al. 2006b), although information on annual rates of sea-ice-associated production is still insufficient. Trawling impacts on the benthos are highest in the areas harboring rich accessible fish stocks, i.e. the ice-free southern areas in particular (Lyubin et al. 2011), but reliable geo-referenced information of trawling pressure for the entire Barents Sea is currently lacking.

\section{Faunal dataset}

Benthic megafaunal abundance and biomass data were derived via the joint Norwegian-Russian Ecosystem Survey (Michalsen et al. 2013). The dataset of 398 bottom trawl stations presented in this study was compiled by experts on 3 Norwegian and 1 Russian research vessel from August to October 2008 and August to October 2009. Samples were taken with a Campelen 1800 bottom trawl, towed for 15 min at 3 


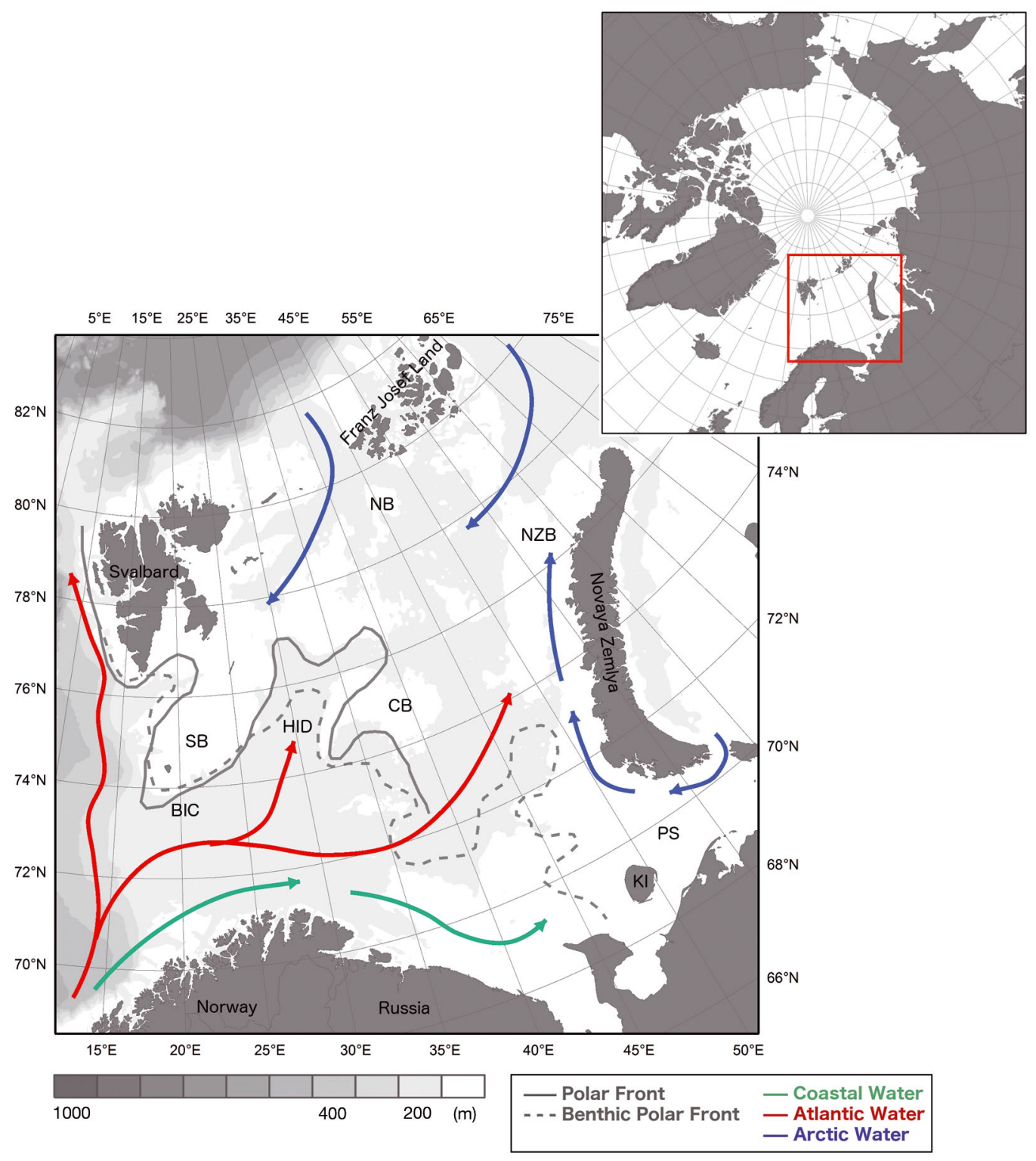

Fig. 1. Barents Sea bathymetry and scheme of the main water masses. The approximate positions of the Polar Front and the Benthic Polar Front are indicated by a grey and a dashed grey line, respectively. Bathymetry is based on the International Bathymetric Chart of the Arctic Ocean basemap (www.ibcao.org). BIC: Bear Island Channel; CB: Central Bank; HID: Hopen Island Deep; KI: Kolguyev Island; NB: North Bank; NZB: Novaya Zemlya Bank; PS: Pechora Sea; SB: Spitsbergen Bank

knots. The horizontal opening of the trawl was $11.7 \mathrm{~m}$, the mesh size varied from $80 \mathrm{~mm}$ (stretched) at the front to $16-22 \mathrm{~mm}$ at the cod end. The standard distance between stations was $65 \mathrm{~km}$. On board ship, the benthic megafauna was separated from the fish and shrimp catch, identified to the species level, and counted, and wet-weight biomass was measured with electronic scales. Colonial species were treated as 1 individual per colony. For more information on the joint Norwegian-Russian Ecosystem Survey, see Michalsen et al. (2013) and Jørgensen et al. (2015).

\section{Environmental dataset}

Water depth $(\mathrm{m})$ was estimated with the ship's depth sounders at each sampling station. Mean bottom water temperature $\left({ }^{\circ} \mathrm{C}\right)$, bottom water salinity (psu), and current speed $\left(\mathrm{m} \mathrm{s}^{-1}\right)$ for the period January 2008 to December 2009 were derived from the numerical ocean model SVIM (Lien et al. 2014). The standard deviation of mean sea ice concentration (\%) of the period 2001 to 2008 was estimated from monthly average sea ice concentration maps provided 
by NORMAP (10 km grid, http://normap.met.no) via an algorithm in $\mathrm{R}$ software. Mean new primary production (NPP; $\mathrm{g} \mathrm{C} \mathrm{m}^{-2} \mathrm{yr}^{-1}$ ) for the period 2001 to 2008 was derived from the SINMOD model (see Wassmann et al. 2006a). New production is a measure of the maximum harvestable production or export production from the system (Wassmann et al. 2006a). As Arctic invertebrate megafauna are on average long-lived (Piepenburg 2005), we presumed the integration of the previous $8 \mathrm{yr}$ to be appropriate for structuring the community composition in 2008 and 2009. Sediment types were characterized into 6 classes based on the classification scheme of Vinogradova \& Litvin (1960), with class 1 being sand, class 2: silty sand, class 3 : sandy silt, class 4: mud, class 5: clay-silt, and class 6: clay. Insufficient information is available on sediments in the Spitsbergen area, and hence we estimated the sediment class for several stations based on information from environmentally comparable reference stations, considering water depth, distance to coast, and current speed as parameters. As georeferenced information on trawling pressure in the Barents Sea is lacking for the years prior to sampling, we categorized the trawling information of the Russian fisheries fleet from 2002 to 2005 (i.e. number of hauls per region), provided in the illustrations of Lyubin et al. (2011), into 4 classes with 1: no trawling, 2: low trawling, 3: intermediate trawling, and 4: high trawling pressure. Table 1 provides minimum, maximum, and mean values of the environmental parameters considered in this study. The total environmental information for each of the 398 stations can be found in the PANGAEA open access library (http://doi.org/ 10.1594/PANGAEA.857279).

\section{Estimating secondary production ( $\mathrm{P})$ and productivity (P:B ratio)}

The secondary production (P) of Barents Sea megafauna was estimated with an empirical artificial neural network model (for detailed information on the model see Brey 2012; for another application in Arctic regions see Nilsen et al. 2006 and Degen et al. 2015). The model is implemented in an excel spreadsheet and can be freely accessed via www.thomasbrey.de/science/virtualhandbook. Abundance and biomass data given as individuals and biomass ( $\mathrm{g}$ wet weight) per 15 min haul, respectively, were recalculated to $\mathrm{m}^{-2}$ by assuming an average trawled area of $18000 \mathrm{~m}^{2}$ per station (Anisimova et al. 2010). As mean body mass $(\mathrm{M})$ in Joules is the main model input parameter, biomass was divided by abundance for each species and station and converted to Joules using the conversion factor database of Brey (2012, database version 4, www.thomas-brey.de/science/ virtualhandbook). Further model input parameters are bottom temperature $(\mathrm{K})$, water depth $(\mathrm{m}), 4$ taxonomic categories (Mollusca, Annelida, Crustacea, Echinodermata), 7 lifestyle categories (infauna, sessile, crawler, facultative swimmer, herbivore, omnivore, carnivore), 4 environmental categories (lake, river, marine, subtidal), and a marker for exploitation. All categorical variables were binary ( 0 or 1 ). The necessary ecological information for each species was extracted from literature and online resources (for a list of literature and web sources, see the Supplement at www.int-res.com/articles/suppl/m546p001_supp.pdf). Species that did not belong to any of the 4 taxonomic categories of the model were grouped by the taxonomic category their body form resembled most. The output of the model is the population production to biomass (P:B) ratio $\left(\mathrm{yr}^{-1}\right)$, including upper and lower $95 \%$ confidence limits. Population P was calculated by multiplying the $\mathrm{P}: \mathrm{B}$ ratio with population biomass, previously converted to $\mathrm{g} \mathrm{C} \mathrm{m}^{-2} \mathrm{yr}^{-1}$. Total community $\mathrm{P}$ was calculated by adding up all population values per station. Production per phylum was calculated for Annelida, Arthropoda, Cnidaria, Echinodermata, Mollusca, and Porifera. The phyla Brachiopoda, Bryozoa, Cephalorhyncha, Chordata, Echiura, Nemertea, Platyhelminthes, and Sipuncula occurred in very low abundances $\left(<0.1\right.$ ind. $\left.\mathrm{m}^{-2}\right)$ and biomasses $\left(<5 \mathrm{mg} \mathrm{C} \mathrm{m}^{-2}\right)$ and were therefore combined into the group 'Others.'
Table 1. Environmental parameters considered in this study: longitude $\left({ }^{\circ} \mathrm{E}\right)$, latitude $\left({ }^{\circ} \mathrm{N}\right)$, water depth $(\mathrm{m})$, temperature $\left({ }^{\circ} \mathrm{C}\right)$, salinity (psu), current speed $\left(\mathrm{m} \mathrm{s}^{-1}\right)$, standard deviation of mean sea ice concentration from 2001 to 2008 $(\%)$, and new primary production (NPP, $\mathrm{g} \mathrm{C} \mathrm{m}^{-2} \mathrm{yr}^{-1}$ )

\begin{tabular}{|lcccccccc|}
\hline & Long. & Lat. & Depth & Temp. & Salinity & Current & Sea ice & NPP \\
\hline Min & 8.90 & 68.47 & 20.00 & -1.49 & 33.34 & 0.00 & 0.00 & 20.23 \\
Max & 75.88 & 82.05 & 485.00 & 5.92 & 35.03 & 0.16 & 39.43 & 93.77 \\
Mean & 35.59 & 74.51 & 248.28 & 1.55 & 34.85 & 0.03 & 15.18 & 65.78 \\
\hline
\end{tabular}

\section{Geostatistical analysis}

$\mathrm{P}, \mathrm{P}: \mathrm{B}$ ratio, NPP, trawling pressure, water depth, temperature, salinity, current speed, standard deviation of mean sea-ice concentration, and sediment structure were projected spatially using a GIS environment (ArcGIS Desktop: Release 10, Environmental Systems 
Research Institute). The WGS 1984 Stereographic North Pole projection was used. The data distribution was visually inspected, and outliers (2 stations) were eliminated from the dataset. All analytical methods applied can be found in the spatial statistics toolbox of ArcGIS (10.1). Grouping analysis based on bottom temperature was used to separate the dataset into a southwestern (SW) and a northeastern (NE) group. Hotspot analysis (Getis-Ord $\mathrm{Gi}^{*}$ ) was used to identify regions of significantly higher $\mathrm{P}$ and $\mathrm{P}: \mathrm{B}$ ratio than the overall mean. This method identifies statistically significant hotspots, i.e. regions where stations with high (or low) values cluster together. The global regression model ordinary least squares (OLS) was used to determine the environmental parameters significantly correlated to the observed patterns of $\mathrm{P}$ and $\mathrm{P}: \mathrm{B}$ ratio. The independent input variables in the OLS model were water depth, temperature, salinity, current speed, sea ice concentration, NPP, trawling pressure, and sediment structure. The significant variables were consequently used as input in the GWR model. GWR accounts for the spatial variability of input data by incorporating spatially varying relationships in the regression analysis (Fotheringham et al. 2002) and was used to visualize the regionally varying relationships between P, P:B ratio, and the explanatory variables. This model is appropriate when more than 100 features (here sample stations) are available, no binary outcomes are predicted, and a projected coordinate system is used. A higher $\mathrm{R}^{2}$ value in the GWR model than in the OLS model and a distinct difference in the corrected Akaike's information criterion (AICC) between the 2 models indicate that the use of GWR was appropriate for the present dataset. All skewed input data were transformed to approach a normal distribution. Salinity data had to be grouped in classes because transformation did not sufficiently reduce skewness. The graphical output of the GWR model are maps of correlation coefficients with hot-to-cold rendering indicating regional variation in the relationship of the dependent and the independent variables. The models were tested to fulfill all required assumptions necessary to guarantee a reliable model output. Moran's I was used to test for potential spatial autocorrelation of the regression residuals.

\section{Additional statistics}

ANOVA was conducted to test for significant differences between the secondary production and the productivity of the faunal group in the SW and the group in the NE Barents Sea (previously identified with grouping analysis in GIS) using the $\mathrm{JMP}^{\circledR}$ software package, Version 10.0 (SAS Institute).

\section{RESULTS}

\section{Total community production (P) and productivity (P:B ratio)}

Total community production per station ranged from 0.015 to $105 \mathrm{mg} \mathrm{C} \mathrm{m}{ }^{-2} \mathrm{yr}^{-1}$ (Table 2, Fig. 2a; http://doi.org/10.1594/PANGAEA.857279). The grouping analysis based on bottom temperature separated the dataset into an NE and an SW part $\left(R^{2}=0.70\right)$. Production was significantly higher in the NE part than in the SW part $(F=106.27, \mathrm{p}<0.0001)$. The hotspot analysis performed on Box-Cox transformed $\mathrm{P}$ data identified 4 hotspots in the northern region

Table 2. Minimum, maximum, and mean of total community abundance (ind. $\mathrm{m}^{-2}$ ), biomass $\left(\mathrm{mg} \mathrm{C} \mathrm{m}^{-2}\right)$, secondary production ( $\mathrm{P} ; \mathrm{mg} \mathrm{C} \mathrm{m}^{-2} \mathrm{yr}^{-1}$ ), and productivity (production to biomass ratio, $\mathrm{P}: \mathrm{B}$ ) per major taxonomic group. The group 'Others' includes taxa occurring in very low numbers $\left(<0.1\right.$ ind. $\left.\mathrm{m}^{-2}\right)$ and biomass $\left(<5 \mathrm{mg} \mathrm{C} \mathrm{m}{ }^{-2}\right)$, i.e. Brachiopoda, Bryozoa, Cephalorhyncha, Echiura, Nemertea, Platyhelminthes, and Sipuncula. Highest mean values for $\mathrm{P}$ and $\mathrm{P}: \mathrm{B}$ ratio are highlighted in bold

\begin{tabular}{|c|c|c|c|c|c|}
\hline & & Abundance & Biomass & Production & on $P: B$ \\
\hline \multirow[t]{3}{*}{ Total } & Min & 0.00 & 0.08 & 0.01 & 0.04 \\
\hline & Max & 3.12 & 950.09 & 104.87 & 0.84 \\
\hline & Mean & 0.11 & 45.16 & 5.32 & 0.15 \\
\hline \multirow{3}{*}{ Annelida } & Min & 0.00 & 0.00 & 0.00 & 0.00 \\
\hline & Max & 1.26 & 57.96 & 33.62 & 1.49 \\
\hline & Mean & 0.02 & 0.79 & 0.65 & 0.61 \\
\hline \multirow[t]{3}{*}{ Arthropoda } & Min & 0.00 & 0.00 & 0.00 & 0.00 \\
\hline & Max & 0.29 & 139.83 & 15.37 & 0.73 \\
\hline & Mean & 0.01 & 6.49 & 0.94 & 0.20 \\
\hline \multirow[t]{3}{*}{ Chordata } & Min & 0.00 & 0.00 & 0.00 & 0.00 \\
\hline & Max & 0.48 & 19.45 & 2.89 & 0.41 \\
\hline & Mean & $<0.01$ & 0.27 & 0.04 & 0.07 \\
\hline \multirow[t]{3}{*}{ Cnidaria } & Min & 0.00 & 0.00 & 0.00 & 0.00 \\
\hline & Max & 0.41 & 261.62 & 21.01 & 0.49 \\
\hline & Mean & 0.01 & 3.06 & 0.26 & 0.12 \\
\hline \multirow{3}{*}{$\begin{array}{l}\text { Echino- } \\
\text { dermata }\end{array}$} & Min & 0.00 & 0.00 & 0.00 & 0.00 \\
\hline & Max & 2.98 & 762.91 & 81.14 & 0.44 \\
\hline & Mean & 0.06 & 27.60 & 2.68 & 0.14 \\
\hline \multirow[t]{3}{*}{ Mollusca } & Min & 0.00 & 0.00 & 0.00 & 0.00 \\
\hline & Max & 0.17 & 210.53 & 33.70 & 0.46 \\
\hline & Mean & 0.01 & 2.24 & 0.37 & 0.17 \\
\hline \multirow[t]{3}{*}{ Porifera } & Min & 0.00 & 0.00 & 0.00 & 0.00 \\
\hline & Max & 0.17 & 267.41 & 12.90 & 0.39 \\
\hline & Mean & $<0.01$ & 3.74 & 0.23 & 0.07 \\
\hline \multirow[t]{3}{*}{ Others } & Min & 0.00 & 0.00 & 0.00 & 0.00 \\
\hline & Max & 0.09 & 80.08 & 11.42 & 0.09 \\
\hline & Mean & $<0.01$ & 0.17 & 0.02 & $<0.01$ \\
\hline
\end{tabular}



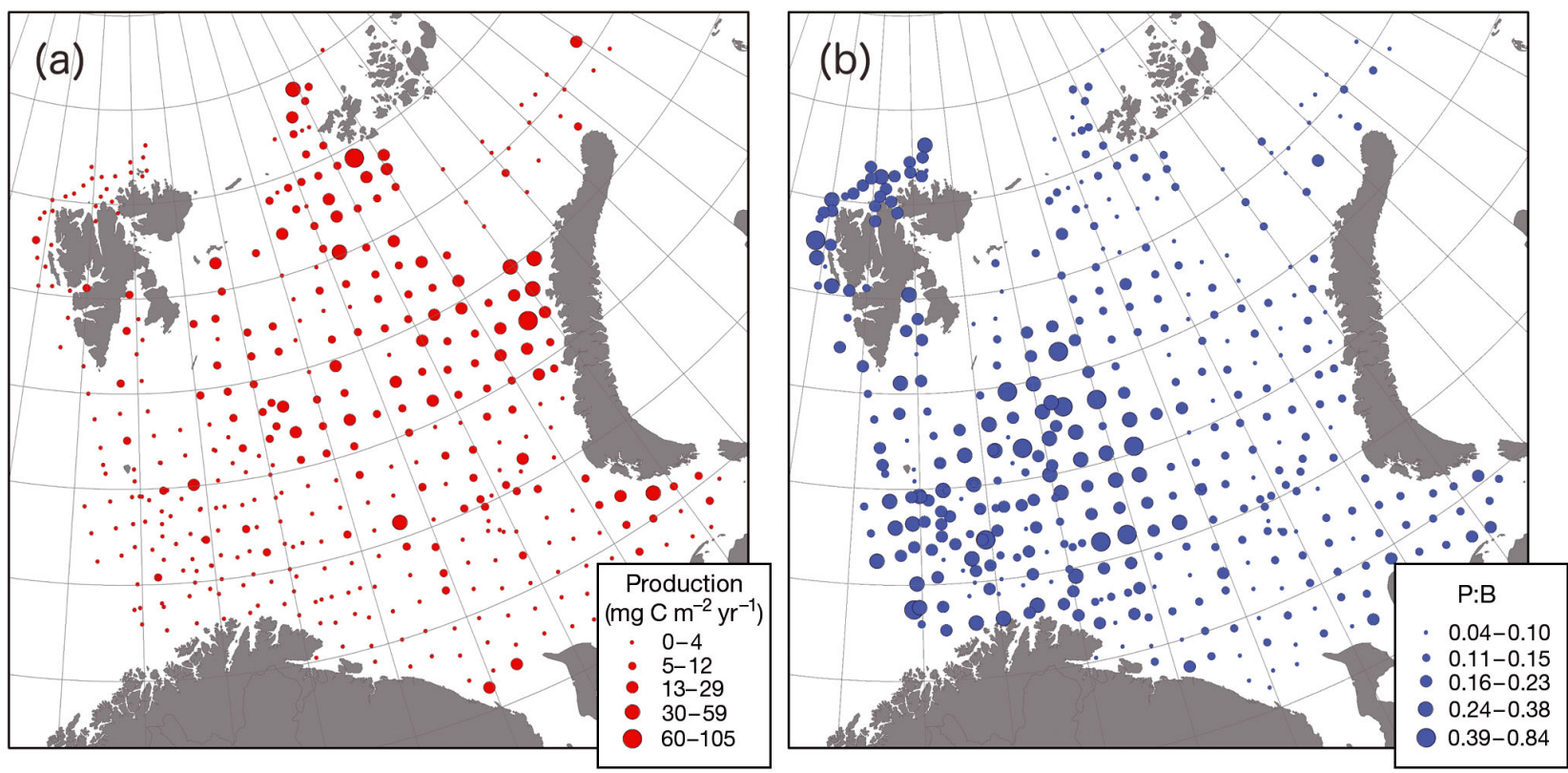

Fig. 2. Total community (a) production (P) $\left(\mathrm{mg} \mathrm{C} \mathrm{m}^{-2} \mathrm{yr}^{-1}\right)$ and (b) productivity (production to biomass ratio, $\mathrm{P}: \mathrm{B}_{;} \mathrm{yr}^{-1}$ )

and 3 coldspots in the south and northwest (Fig. 3a). The largest hotspot area is located west of Novaya Zemlya, and the hotspot with the highest local benthic production is located SW of Franz Josef Land (North Bank). Another hotspot is located on the southern slope of Novaya Zemlya, and the smallest resides in the central Barents Sea (Hopen Island Deep and western slopes of the Central Bank). The geographically largest coldspot is located in the SW
Barents Sea. The 2 other and geographically smaller coldspots are located northwest of Spitsbergen and in the southeast, west of Kolguyev Island. Total community productivity (P:B ratio) ranged from 0.038 to 0.841 (Table 2, Fig. 2b). The P:B ratio was not significantly different between the SW and the NE region $(F=$ 3.00; $\mathrm{p}=0.084$ ), but the highest $\mathrm{P}: \mathrm{B}$ ratios were found in the SW region (Fig. 2b). The hotspot analysis identified 1 large hotspot in the central Barents Sea
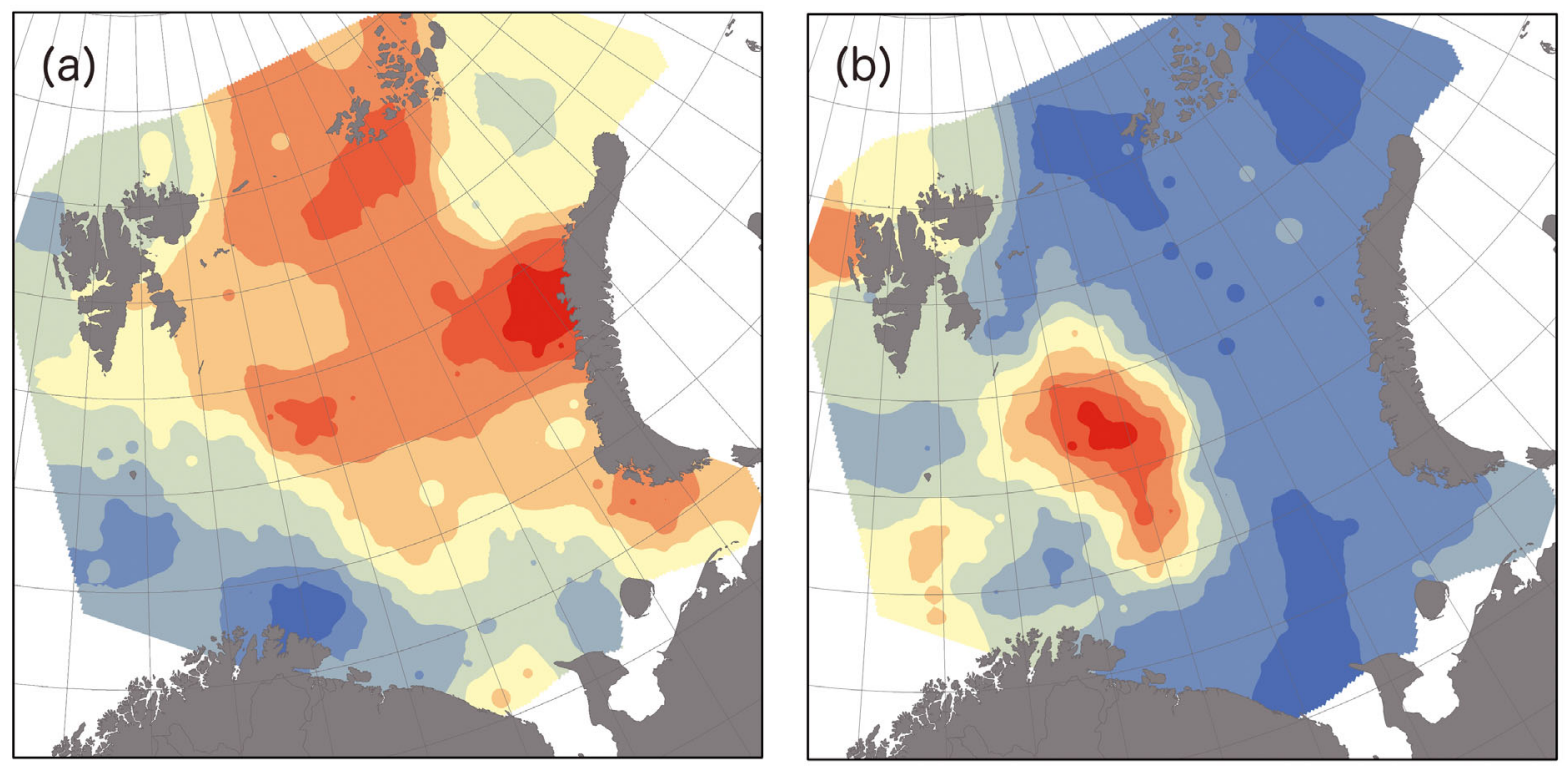

Fig. 3. Interpolated (inverse distance weighting method) standard deviation of $G^{*}$ scores of the hotspot analysis of total community (a) production (P) and (b) the production to biomass ratio (P:B). Red indicates significantly higher values than the mean; blue indicates significantly lower values than the mean 
Table 3. Results of the ordinary least squares (OLS) and geographically weighted regression (GWR) models for total community production and the production to biomass ratio $(P: B)$. Significant parameters $(p<0.05)$ are highlighted in bold. NPP: new primary production, AICC: corrected Akaike's information criterion

\begin{tabular}{|c|c|c|c|c|}
\hline & \multicolumn{2}{|c|}{$\ldots$ Production -} & \multicolumn{2}{|l|}{$-\mathrm{P}: \mathrm{B}$} \\
\hline & Coefficient & $\mathrm{p}$ & Coefficient & $\mathrm{p}$ \\
\hline \multicolumn{5}{|l|}{ OLS } \\
\hline Depth (m) & -0.002 & 0.1778 & 0.000 & 0.2785 \\
\hline Temperature $\left({ }^{\circ} \mathrm{C}\right)$ & -0.835 & $<0.0001$ & 0.005 & 0.0457 \\
\hline Salinity (class) & 0.947 & $<0.0001$ & 0.001 & 0.7534 \\
\hline Current speed $\left(\mathrm{m} \mathrm{s}^{-1}\right)$ & -46.990 & 0.0112 & 1.293 & 0.0069 \\
\hline Sea ice concentration (SD) & 1.138 & 0.0048 & 0.028 & 0.0079 \\
\hline $\mathrm{NPP}\left(\mathrm{mg} \mathrm{C} \mathrm{m}{ }^{-2} \mathrm{yr}^{-1}\right)$ & -0.034 & 0.0082 & 0.002 & $<0.0001$ \\
\hline Trawling pressure & 0.320 & 0.0015 & -0.006 & 0.0144 \\
\hline Sediment (class) & 0.118 & 0.3961 & 0.005 & 0.1853 \\
\hline $\mathrm{R}^{2}$ & \multicolumn{2}{|c|}{0.415} & \multicolumn{2}{|c|}{0.151} \\
\hline AICc & \multicolumn{2}{|c|}{1800.112} & \multicolumn{2}{|c|}{-1114.108} \\
\hline \multicolumn{5}{|l|}{ GWR } \\
\hline $\mathrm{R}^{2}$ & \multicolumn{2}{|c|}{0.734} & \multicolumn{2}{|c|}{0.527} \\
\hline $\mathrm{AICc}$ & \multicolumn{2}{|c|}{88.402} & \multicolumn{2}{|c|}{-59.511} \\
\hline
\end{tabular}

Spitsbergen and north of Novaya Zemlya, Arthropods have a hotspot in the southwestern Barents Sea, north of Novaya Zemlya, and in the Pechora Sea, and Mollusca have a P:B ratio hotspot in the SW and southern Barents Sea and in the Pechora Sea. The figures of $\mathrm{P}$ and $\mathrm{P}: \mathrm{B}$ ratio per major group can be found in Figs. S1 \& S2 in the Supplement, and detailed information about regional megafauna community composition based on a dataset from the year 2011 can be found in Jørgensen et al. (2015).

\section{Global model (OLS)}

The OLS model for secondary production fitted the data with $\mathrm{R}^{2}=0.41$ and an AICc of 1800.12. The AICc is a measure of the relative quality of a statistical model for a given dataset; accor-

(Hopen Island Deep and western slopes of the Central Bank) and 2 smaller hotspots northwest of Spitsbergen and in the southwest deep Bear Island Chandingly, it can be used to compare OLS and GWR models based on the same input parameters. The OLS model identified 6 parameters that explained nel (Fig. 3b).

\section{Major group production (P) and productivity ( $\mathrm{P}: \mathrm{B}$ ratio)}

Echinodermata clearly dominate the megabenthic production in the Barents Sea by contributing $50 \%$ to the total production, followed by Arthropoda (18\%), Annelida $(12 \%)$, and Mollusca (7\%). Cnidaria, Porifera, and all other taxa contribute below $5 \%$. The overall pattern of $\mathrm{P}$ is mainly shaped by Echinodermata and Arthropoda, with both showing clear hotspots in the western area of Franz Josef Land and in the southeastern Barents Sea (see Fig. S1 in the Supplement at www.int-res.com/articles/ suppl/m546p001_supp.pdf). Arthropods have a third hotspot on the Novaya Zemlya Bank. Regarding biomass (mg $\mathrm{C} \mathrm{m}^{-2}$ ), the pattern is different, with Echinodermata contributing $61 \%$, Arthropoda $14 \%$, and Porifera $8 \%$ to the overall biomass. Highest productivity was found in the phyla Annelida (mean 0.61), Arthropoda (0.20), and Mollusca (0.17) (Table 2). Annelida have productivity hotspots in the SW Barents Sea, north of

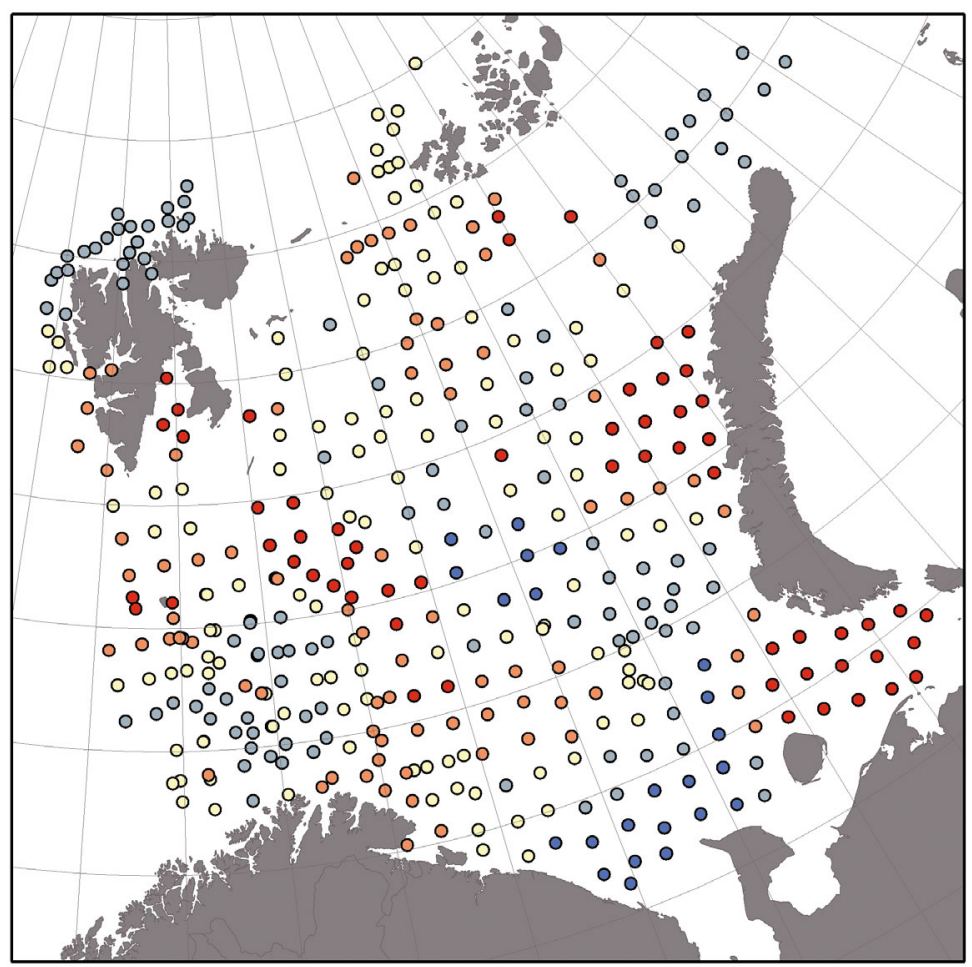

Fig. 4. Mapped $\mathrm{R}^{2}$ values from the geographically weighted regression (GWR) model of megabenthic secondary production (P). Dark red points indicate areas with highest model fit $\left(\mathrm{R}^{2}\right.$ values $\left.0.62-0.82\right)$; blue points indicate areas of low model fit 
the observed production patterns significantly (Table 3). The OLS model for the P:B ratio had a model fit of $\mathrm{R}^{2}=0.15$ and $\mathrm{AICC}=-1114.12$ and identified 5 parameters that significantly explained the variance in the P:B ratios (Table 3). Here, a significant Jarque-Bera statistic $(p=0.0036)$ indicated severe model bias.

\section{Local model (GWR)}

The GWR model for production (P) based on the 6 significant variables identified with OLS (Table 3) displayed an overall model fit of $\mathrm{R}^{2}=0.73$ and $\mathrm{AICC}=$ 88.40. The GWR model for productivity (P:B ratio) based on the 4 significant variables identified with OLS had an overall model fit of $\mathrm{R}^{2}=0.53$ and $\mathrm{AICC}=$ -59.51. The spatial distribution of stations with the highest model fit is shown in Fig. 4. The 6 significant correlation coefficients identified with GWR (shown in Fig. 5a-f) highlight the regionally varying relationships of production and the environment. As the GWR model of P:B ratio is based on potentially biased assumptions from the OLS model, it should be interpreted cautiously. Consequently, we restrain from interpreting spatial P:B ratio patterns and model output in this study.

\section{DISCUSSION}

\section{Remarks on the methodology}

Data from trawl samples are generally considered semi-quantitative and gross estimates (Eleftheriou \& Moore 2005). However, when trawling is carried out consistently over a large number of stations, as was the case in the joint Norwegian-Russian Ecosystem Survey (Michalsen et al. 2013), relative spatial patterns can be identified (Mueter \& Litzow 2008, Fossheim et al. 2015, Jørgensen et al. 2015). In this study, we accordingly do not present estimated secondary production per station or in detail, but rather focus on the regional differences and relationships.

\section{Patterns of megabenthic secondary production}

Secondary production of Barents Sea megafauna is significantly higher in the NE seasonally ice-covered areas than in the permanently ice-free SW areas. We detected 4 regional hotspots of megabenthic secondary production: the area west of and on the southern slope of Novaya Zemlya, the region southwest of Franz Josef Land, and a smaller hotspot in the central Barents Sea. All of these regions of high megafaunal production correspond to the regions of high benthic biomass reported in previous studies (Zenkevitch 1963, Denisenko 2001, 2002, Wassmann et al. 2006b). The region southwest of Franz Josef Land was only mentioned by Zenkevitch (1963), but not in other studies, probably because the regions $>78^{\circ} \mathrm{N}$ were not included in later expeditions due to dense ice cover that impeded sampling (see results assembled by Wassmann et al. 2006b). The region of Spitsbergen Bank (Fig. 1), previously reported as a region of high benthic biomass (Zenkevitch 1963, Denisenko 2001, 2002, Wassmann et al. 2006b, Cochrane et al. 2012, Kedra et al. 2013), was not identified as a hotspot, neither in biomass nor in production, in our megafauna study. Jørgensen et al. (2015) found intermediate biomasses in this area in their analysis of trawl data from the year 2011. One possible explanation for this discrepancy was proposed by Denisenko (2001): the author found a significant negative correlation of benthic biomass with the intensity of bottom trawling and concluded that trawling is one of the main causal factors of long-term fluctuations of bottom communities in the Barents Sea.

The relative contribution of major taxonomic groups to overall benthic secondary production was clearly dominated by Echinodermata, leading with $50 \%$, followed by Arthropoda with $18 \%$ and Annelida with $12 \%$ (see also Table 2). Regarding biomass (mg C m${ }^{-2}$ ), the dominance of Echinodermata was even clearer with $61 \%$ of the overall biomass, followed by Arthropoda with $14 \%$, a pattern also reported to be typical for epibenthic communities in the Pacific Arctic (Bluhm et al. 2009, Grebmeier et al. 2015a). Studies based on quantitative sampling methods have reported a different biomass pattern, with Mollusca (predominantly bivalves) dominating with $35 \%$ before Echinodermata with 19\% and Arthropoda with $15 \%$ (Wassmann et al. 2006b). In accordance with Jørgensen et al. (2011), who compared the sample efficiency of Van Veen grabs (quantitative) and beam trawls (qualitative), we recommend the use of complementary techniques in future studies to ensure the sampling of the entire benthic community at each station. The studies by Grebmeier et al. (2015b) from the Chukchi Sea or by Kedra et al. (2013) from the Spitsbergen Bank are good examples of how the use of multiple sampling devices leads to a better understanding of the entire benthic community. Nevertheless, several studies performed on smaller spatial scales confirm the dom- 

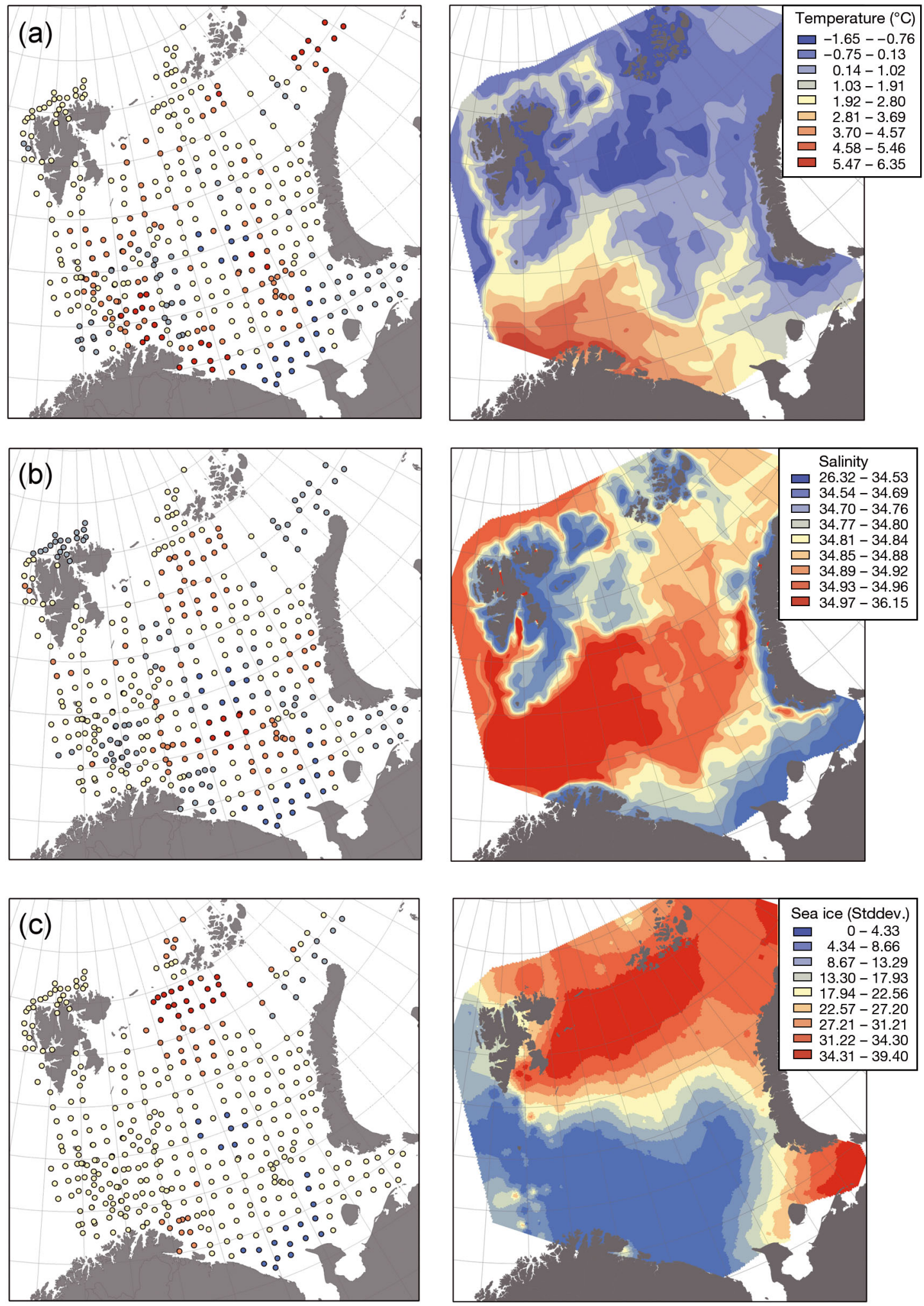

Fig. 5. Correlation coefficients derived from the geographically weighted regression (GWR) megafauna production model for the 6 significant parameters: (a) bottom temperature, (b) salinity, (c) sea-ice concentration (standard deviation), (d) new primary production (NPP), (e) trawling pressure, and (f) current speed. Red circles in left panels indicate significant positive correlations; blue circles indicate significant negative correlations of secondary production (P) and the respective parameter. The maps on the right show the interpolated (inverse distance weighting method) environmental parameters, with red, blue, and yellow areas indicating high, low, and intermediate values, respectively 

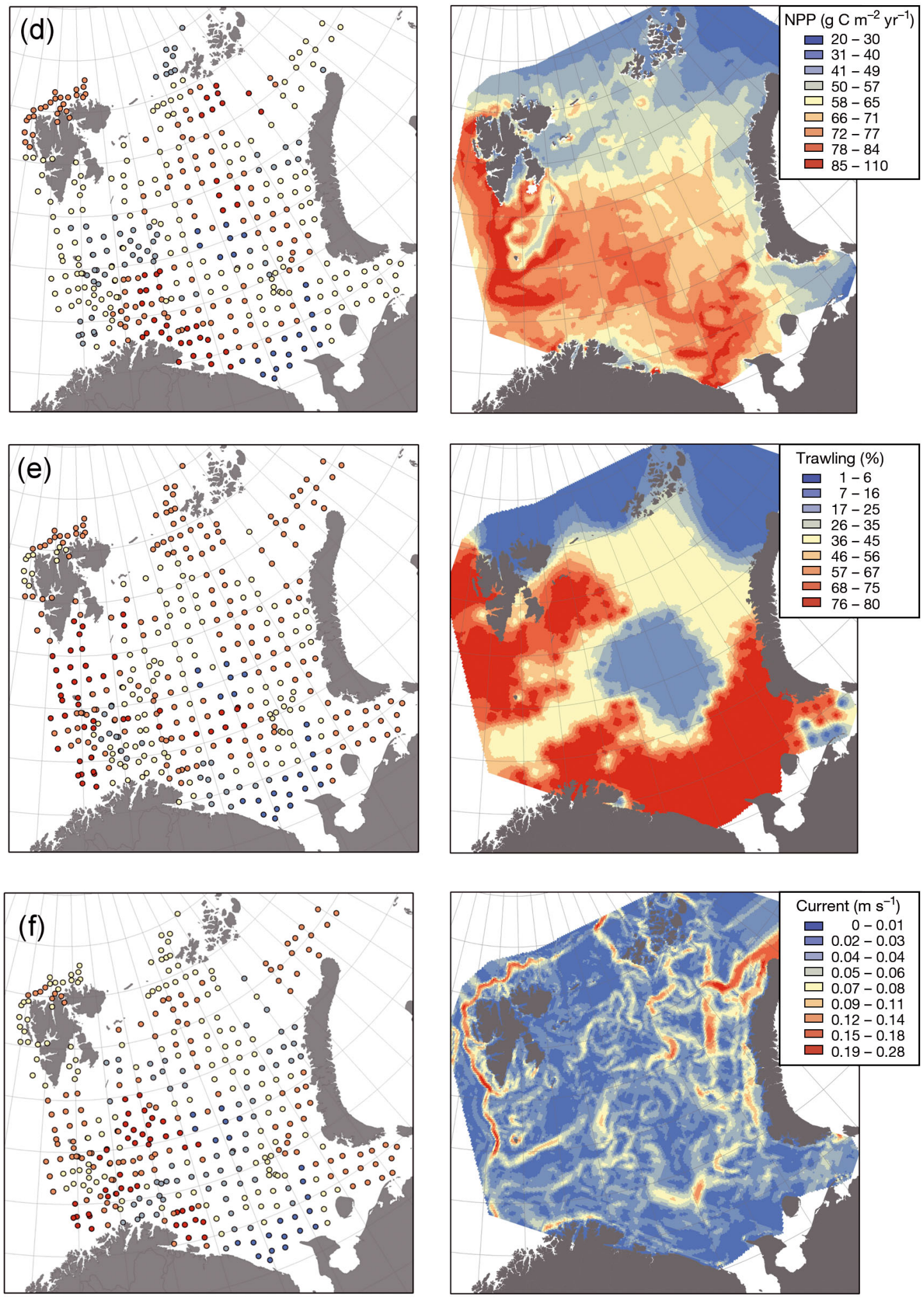

Fig. 5 (continued) 
inance of echinoderms in the overall benthic biomass and energy flow on Arctic shelves (Piepenburg 2005 and references therein, Renaud et al. 2007).

\section{Drivers of megabenthic secondary production}

At large regional scales, food input is reported to be the main driver of distribution and biomass of benthos, and of benthic production accordingly (Grebmeier et al. 1988, Piepenburg 2005). Arctic benthic biomass hotspots were previously reported to coincide with areas of high primary production and with ice-edge areas (Denisenko 2002, Wassmann et al. 2006b, Carroll et al. 2008, Grebmeier et al. 2015a). We used NPP (Wassmann et al. 2006a) as a proxy of food input to the benthos in our regression model and expected a positive correlation with megabenthic production, i.e. high $\mathrm{P}$ values in areas of high NPP. However, we found a reverse pattern: P was negatively related with NPP and was significantly higher in regions that are seasonally sea ice covered and reported to be of distinctly lower pelagic primary production (Wassmann et al. 2006b).

Besides the negative correlation with NPP, we found $\mathrm{P}$ to be negatively correlated with bottom water temperature, positively with salinity, and positively with the standard deviation of sea ice concentration. All of these factors relate to some extent to the marginal ice zone (MIZ). Temperature relates to the MIZ because in the Barents Sea, the maximum extent of colder Arctic water masses and the Polar Front often coincides with the sea ice extent in winter or early spring (Wassmann et al. 2006b). Salinity effects on $\mathrm{P}$ were significant in areas where strong mixing between Atlantic and Arctic water masses occurs, i.e. along the Polar Front (Wassmann et al. 2006b). The standard deviation of sea ice concentration is an obvious proxy for the MIZ. The bulk of the total annual primary production of the northern and NE Barents Sea takes place in the MIZ (Denisenko 2002, Wassmann et al. 2006a, Sakshaug et al. 2009). Spring ice melt gives rise to a nutrient-rich euphotic zone that supports a distinct phytoplankton bloom in the MIZ which moves constantly poleward while receding from its winter position at the Polar Front (Piepenburg et al. 1995, Wassmann et al. 2006a, Leu et al. 2015). This ice-edge bloom induces vertical carbon flux, which might be especially high in spring, before pelagic production and consumption are balanced, or in years where a mismatch between primary and secondary producers occurs (Tamelander et al. 2006, Eiane \& Tande 2009, Leu et al. 2015). The recent study by Leu et al. (2015) suggested highest fluxes of ice-related POM and thus strongest sympagic-pelagic-benthic coupling in the post-bloom phase in late spring, when large aggregates of ice algae are released from the ice. Additionally, deep vertical mixing in the area of the Polar Front enhances the export of high-quantity and high-quality particulate organic carbon (POC), thus favoring tight pelagic-benthic coupling (Olli et al. 2002, Reigstad et al. 2008). Wiedmann et al. (2014) emphasized the role of mixing and turbulence for POC export to deeper areas: they showed that export of POC can be high in post-bloom situations, given that vertical mixing occurs. Tamelander et al. (2006) analyzed the pelagic-benthic coupling in the Barents Sea MIZ during summer and detected tight coupling between surface production and the benthic community over relatively small scales. Additionally, they detected a high degree of heterogeneity, determined by water mass properties like local upwelling and primary production regimes. Our benthic secondary production estimates reflect this patchiness (Fig. 2), as there are 4 significant hotspots and high variability between stations that are on average just $65 \mathrm{~km}$ apart (Fig. 3, http://doi.org/10.1594/PANGAEA.857279).

We further investigated the strength of the pelagic-benthic coupling in the northern seasonally ice-covered region compared to the ice-free southern regions by means of an 'inverse' approximation. The ratio of mean secondary production $(\mathrm{P})$ to mean NPP (0.003:76 $\left.\mathrm{g} \mathrm{C} \mathrm{m}^{-2} \mathrm{yr}^{-1}\right)$ in the southern region is 0.00004 ; in the northern region it is 0.00016 (0.008:50 $\left.\mathrm{g} \mathrm{C} \mathrm{m}^{-2} \mathrm{yr}^{-1}\right)$. This distinctly higher ratio in the north indicates that here, either a larger part of the NPP is channeled to the benthos (i.e. tighter pelagic-benthic coupling), as also suggested by Reigstad et al. (2008), or there is additional NPP that is as yet not accounted for. Kedra et al. (2013) estimated a benthic carbon demand of up to $70 \mathrm{~g} \mathrm{C} \mathrm{m}^{-2}$ $\mathrm{yr}^{-1}$ to sustain the mean epibenthic production of $\sim 22 \mathrm{~g} \mathrm{~m}^{-2} \mathrm{yr}^{-1}$ at the Spitsbergen Bank. As this region was a coldspot in our study, we assume a significantly higher benthic carbon demand in the regions south and west of Novaya Zemlya or SW of Franz Josef Land, which we identified as hotspots of megabenthic production (Fig. 3a). The mean estimated NPP for these regions is $50 \mathrm{~g} \mathrm{C} \mathrm{m}^{-2} \mathrm{yr}^{-1}$. If we add a suggested contribution of ice algae primary production of a maximum of $25 \%$ (Wassmann et al. 2006b), we would reach around $60 \mathrm{~g} \mathrm{C} \mathrm{m}^{-2} \mathrm{yr}^{-1}$, not enough to fulfill a carbon demand of potentially much more than $70 \mathrm{~g} \mathrm{C} \mathrm{m}^{-2} \mathrm{yr}^{-1}$ (Kedra et al. 2013). Consequently, we assume that the production of sea-ice 
algae and accordingly also the overall NPP in these regions might be considerably higher than previously anticipated. Although reliable estimates of ice algal production on large spatial scales are lacking, our assumption is supported by several studies from other Arctic regions (see Leu et al. 2015 and references therein). In the Canadian Arctic, Matrai \& Apollonio (2013) found ice and sub-ice microalgae to contribute up to $50 \%$ to total net community production. Gradinger (2009) reported that on the shelves and slope regions of the Chukchi and Beaufort Seas, sea-ice primary production exceeds water-column primary production significantly in early spring. The few studies that have analyzed the benthic utilization of sea-ice algae could indicate that benthic communities use sea-ice algae as rapidly as phytoplankton (McMahon et al. 2006, Sun et al. 2007).

Additionally to the POC fluxes from the sea ice, there might also be a substantial contribution of advected material originating from pelagic production or from shallower macroalgae areas (Rosenberg 1995, Renaud et al. 2007, 2015), like along the shelf of Novaya Zemlya and Franz Josef Land. Renaud et al. (2007) pointed out that advected matter originating tens of kilometers away could in fact explain the enhanced benthic community oxygen demand they observed in their study from the Beaufort Sea, but also underpin the coincidence of the onset of algal growth with the increase in benthic respiration they observed in the same region. Renaud et al. (2015) showed that most benthic taxa in an Arctic fjord feed on a broad mixture of POM and macroalgal detritus, even at depths $>400 \mathrm{~m}$, thus strengthening the importance of macroalgae as food source at least for near-shore benthic communities.

The exclusion of smaller benthic size classes, the meio- and macrofauna, from this study could be another explanation for the non-correlation of food input - here NPP — and benthic secondary production. A recent study from the Pacific Arctic indicates that macrofaunal biomass is linked more closely to food supply than the megabenthic epifauna (Grebmeier et al. 2015b). The authors presumed that mobility may explain this pattern: while the more stationary macrofauna reflects the local food input (either from sedimentation or from advection) more closely, the larger mobile species are capable of exploiting wider areas and a greater variety of food sources. This opportunism may also be an important strategy during the polar night, when photosynthetic production is absent and alternative food sources or stored reserves must be exploited (Berge et al. 2015). Berge et al. (2015) found evidence of this oppor- tunism in the rapid response of benthic scavengers to food-fall items, as well as in the continuous annual growth of a suspension feeder.

A similar pattern of clearly higher biomass in the NE Barents Sea was reported for the mesozooplankton sampled during the joint Norwegian-Russian Ecosystem survey in 2009 (Orlova et al. 2011). The Arctic copepods Calanus glacialis and C. hyperboreus, both grazers on phytoplankton and ice algae, clearly dominated the mesozooplankton biomass, a pattern also reported from the zooplankton community in the Beaufort Sea (Darnis et al. 2008). The calanoid copepods have an up to 2 yr life cycle and, at least at certain developmental stages, spend the overwintering period near the bottom (Melle \& Skjoldal 1998, Berge et al. 2015). We assume that especially during the polar night the accumulated biomass of more than 1 generation of copepods might constitute a substantial food source to benthic predators and scavengers (Jørgensen et al. 2015).

Apart from the environmental parameters that are related to the MIZ and to food input, we further detected a significant negative correlation between $\mathrm{P}$ and current speed and a positive correlation between $\mathrm{P}$ and trawling pressure. The former can be related to the fact that regions with high current speed are often dominated by filter feeders, such as Porifera, Bryozoa, Hydrozoa, ascidians, and epifaunal bivalves that contributed little to overall $\mathrm{P}$ in this study. The positive correlation to trawling pressure was unexpected, as a previous study along the Kola transect showed a significant negative correlation between benthic biomass and bottom trawling (Denisenko 2001). Our findings probably relate to the fact that long-term bottom trawling changes the age and size spectrum of benthic communities from long-lived, large sized individuals to short-lived, smaller sized individuals and species (Callaway et al. 2007), an effect also observed after ice scour disturbances (e.g. Conlan et al. 1998). As the P:B ratio is inversely related to body size, this shift increases the community $\mathrm{P}: \mathrm{B}$ ratio and most likely community $\mathrm{P}$ as well.

\section{Regionally varying relationships}

Overall, our geo-statistical approach shows that the tight pelagic-benthic coupling along the productive, seasonally moving ice edge is of crucial importance for northern Barents Sea megabenthic production. Apart from the differences on large spatial scales, the GWR approach enabled us further to investigate the regional variation in the correlation between $\mathrm{P}$ and 
environmental parameters (Fig. 5a-f). Here, we focus on salinity (Fig. 5b) and on sea-ice concentration (Fig. 5c). Salinity is correlated positively with $\mathrm{P}$ in a regional band resembling the approximate position of the Benthic Polar Front (Figs. 1 \& 5b), thus indicating the relevance of mixed water masses along the MIZ for benthic production. The standard deviation of sea ice concentration shows the highest positive correlation with $\mathrm{P}$ southwest of Franz Josef Land (Fig. 5c), the region where the highest $\mathrm{P}$ values were observed in this study (Fig. 3a). This may point towards the importance of sea-ice algae for benthic secondary production in this region, as the ice-algal contribution to overall primary production was reported to be proportionally more important in areas where sea ice retreats later in the year (Gosselin et al. 1997, Carroll \& Carroll 2003). Denisenko (2002) showed for the Barents Sea, but also for the Kara, Laptev, East-Siberian, and Chukchi Seas, that areas of high benthic biomass matched well with areas of the longest duration of average multiyear ice cover. Either way, our findings highlight the effectiveness of GWR in identifying areas where particular relationships between environmental and ecological features exist that should be studied in more detail.

\section{CONCLUSIONS AND OUTLOOK}

We found significantly higher megabenthic secondary production in the northern, seasonal icecovered Barents Sea than in the southern, ice-free region. We conclude that tighter pelagic-benthic coupling in the northern area, and regionally varying environmental conditions, like local upwelling and tidal mixing, explain the observed pattern. The negative correlation of $\mathrm{P}$ to NPP, used here as a proxy for food input to the benthos, might be explained to a certain extent by an underestimation of the modeled NPP. Additionally, the (unknown) influence of advection processes must be taken into account. A further explanation for the non-correlation between primary and secondary production might be that this relationship is less distinct in the highly mobile epibenthic megafauna (Grebmeier et al. 2015b). Hence, we presume that a more holistic approach including all benthic size classes would yield the expected positive correlation of benthic secondary production with primary production on large spatial scales.

Regarding the anticipated further poleward movement of the MIZ, our findings indicate that benthic production in the Barents Sea might decrease significantly, owing to the diminishing shelf area influ- enced by ice-edge processes and dynamics. Simultaneously, primary and secondary production in the southern, ice-free regions might decrease as well, due to increasing thermal stratification (Slagstad et al. 2015). Accordingly, we expect cascading effects of these changes on all levels of the Barents Sea ecosystem. These prospects stress the importance of continuous integrated monitoring programs, such as the joint Norwegian-Russian Ecosystem Survey, that can provide sound scientific advice on ecosystem management.

Acknowledgements. We thank the graduate program POLMAR for funding R.D., and Vidar S. Lien (IMR) for provision of modeled environmental data. Thanks to the Institute of Marine Research and PINRO for including benthic experts in the annual Ecosystem Survey. The crews and the Russian and Norwegian benthic taxonomists onboard the Russian and Norwegian research vessels are thanked for the collection, identification, and quantification of the benthic fauna. We also thank the Norwegian Ministry of Foreign Affairs for economic support of exchange of Russian and Norwegian scientists between the research vessels.

\section{LITERATURE CITED}

Anisimova NA, Jørgensen LL, Lyubin PA, Manushin IE (2010) Mapping and monitoring of benthos in the Barents Sea and Svalbard waters: results from the joint Russian-Norwegian benthic programme 2006-2008. IMRPINRO Joint Report Series 1-2010

Benke A (2012) Secondary production. Nat Educ Knowl 3:23 - Berge J, Daase M, Renaud PE, Ambrose WG and others (2015) Unexpected levels of biological activity during the polar night offer new perspectives on a warming Arctic. Curr Biol 25:2555-2561

Bluhm BA, Piepenburg D, von Juterzenka K (1998) Distribution, standing stock, growth, mortality and production of Strongylocentrotus pallidus (Echinodermata: Echinoidea) in the northern Barents Sea. Polar Biol 20:325-334

Bluhm BA, Iken K, Mincks Hardy S, Sirenko BI, Holladay BA (2009) Community structure of epibenthic megafauna in the Chukchi Sea. Aquat Biol 7:269-293

Brey T (2012) A multi-parameter artificial neural network model to estimate macrobenthic invertebrate productivity and production. Limnol Oceanogr Methods 10: 581-589

Callaway R, Engelhard GH, Dann J, Cotter J, Rumohr H (2007) A century of North Sea epibenthos and trawling: comparison between 1902-1912, 1982-1985 and 2000. Mar Ecol Prog Ser 346:27-43

Carroll ML, Carroll J (2003) The Arctic Seas. In: Black K, Shimmield G (eds) Biogeochemistry of marine systems. Blackwell Publishing, Oxford, p 127-156

Carroll ML, Denisenko SG, Renaud PE, Ambrose WG Jr (2008) Benthic infauna of the seasonally ice-covered western Barents Sea: patterns and relationships to environmental forcing. Deep-Sea Res II 55:2340-2351

Clough LM, Renaud PE, Ambrose WG (2005) Impacts of water depth, sediment pigment concentration, and benthic macrofaunal biomass on sediment oxygen demand 
in the western Arctic Ocean. Can J Fish Aquat Sci 62: 1756-1765

> Cochrane SKJ, Denisenko SG, Renaud PE, Emblow CS, Ambrose WG Jr, Ellingsen IH, Skarðhamar J (2009) Benthic macrofauna and productivity regimes in the Barents Sea-ecological implications in a changing Arctic. J Sea Res 61:222-233

Cochrane SKJ, Pearson TH, Greenacre M, Costelloe J, Ellingsen IH, Dahle S, Gulliksen B (2012) Benthic fauna and functional traits along a Polar Front transect in the Barents Sea-Advancing tools for ecosystem-scale assessments. J Mar Syst 94:204-217

> Conlan KE, Lenihan HS, Kvitek RG, Oliver JS (1998) Ice scour disturbance to benthic communities in the Canadian High Arctic. Mar Ecol Prog Ser 166:1-16

- Dalpadado P, Arrigo KR, Hjøllo SS, Rey F and others (2014) Productivity in the Barents Sea-response to recent climate variability. PLoS One 9:e95273

Darnis G, Barber DG, Fortier L (2008) Sea ice and the onshore-offshore gradient in pre-winter zooplankton assemblages in southeastern Beaufort Sea. J Mar Syst 74: 994-1011

> Degen R, Vedenin A, Gusky M, Boetius A, Brey T (2015) Patterns and trends of macrobenthic abundance, biomass and production in the deep Arctic Ocean. Polar Res $34: 24008$

Denisenko SG (2001) Long-term changes of zoobenthos biomass in the Barents Sea. Proc Zool Inst Russ Acad Sci 289:59-66

Denisenko S (2002) Zoobenthos and ice distribution in the Arctic seas. Proc Zool Inst Russ Acad Sci 296:39-46

Dommasnes A, Christensen V, Ellertsen B, Kvamme C and others (2001) An Ecopath model for the Norwegian Sea and Barents Sea. 2001: fisheries impacts on North Atlantic ecosystems. Fish Cen Res Rep 9:213-239

Eiane K, Tande KS (2009) Meso and macrozooplankton. In: Sakshaug E, Johnsen G, Kovacs K (eds) Ecosystem Barents Sea. Tapir Academic Press, Trondheim, p 209-234

Eleftheriou A, Moore DC (2005) Macrofauna techniques. In: Eleftheriou A (ed) Methods for the study of marine benthos. Blackwell Science, Oxford, p 160-228

Fossheim M, Primicerio R, Johannesen E, Ingvaldsen Randi B, Aschan MM, Dolgov AV (2015) Recent warming leads to a rapid borealization of fish communities in the Arctic. Nat Clim Change 5:673-678

Fotheringham AS, Brunsdon C, Charlton ME (2002) Geographically weighted regression: the analysis of spatially varying relationships. Wiley, Chichester

Gosselin M, Levasseur M, Wheeler PA, Horner RA, Booth BC (1997) New measurements of phytoplankton and ice algal production in the Arctic Ocean. Deep-Sea Res II 44:1623-1644

> Gradinger R (2009) Sea ice algae: major contributors to primary production and algal biomass in the Chukchi and Beaufort Seas during May/June 2002. Deep-Sea Res II 56:1201-1212

Grebmeier JM, McRoy CP, Feder HM (1988) Pelagic-benthic coupling on the shelf of the northern Bering and Chukchi Seas. I. Food supply source and benthic biomass. Mar Ecol Prog Ser 48:57-67

> Grebmeier JM, Cooper LW, Feder HM, Sirenko BI (2006) Ecosystem dynamics of the Pacific-influenced Northern Bering and Chukchi Seas in the Amerasian Arctic. Prog Oceanogr 71:331-361

> Grebmeier JM, Bluhm BA, Cooper LW, Danielson S and others (2015a) Ecosystem characteristics and processes facilitating persistent macrobenthic biomass hotspots and associated benthivory in the Pacific Arctic. Prog Oceanogr 136:92-114

Grebmeier JM, Bluhm BA, Cooper LW, Denisenko SG, Iken K, Kędra M, Serratos C (2015b) Time-series benthic community composition and biomass and associated environmental characteristics in the Chukchi Sea during the RUSALCA 2004-2012 Program. Oceanography 28: 116-133

Highsmith RC, Coyle KO (1990) High productivity of northern Bering Sea benthic amphipods. Nature 344: 862-863

Ingvaldsen R, Loeng $H$ (2009) Physical oceanography. In: Sakshaug E, Johnsen G, Kovacs K (eds) Ecosystem Barents Sea. Tapir Academic Press, Trondheim, p 33-64

Jakobsson M, Grantz A, Kristoffersen Y, Macnab R (2004) Bathymetry and physiogeography of the Arctic Ocean and its constituent seas. In: Stein R, Macdonald RW (eds) The Arctic Ocean organic carbon cycle: present and past. Springer, Berlin, p 1-6

> Jørgensen LL, Renaud PE, Cochrane SKJ (2011) Improving benthic monitoring by combining trawl and grab surveys. Mar Pollut Bull 62:1183-1190

> Jørgensen LL, Ljubin P, Skjoldal HR, Ingvaldsen RB, Anisimova N, Manushin I (2015) Distribution of benthic megafauna in the Barents Sea: baseline for an ecosystem approach to management. ICES J Mar Sci 72:595-613

Kędra M, Renaud PE, Andrade H, Goszczko I, Ambrose WG Jr (2013) Benthic community structure, diversity, and productivity in the shallow Barents Sea bank (Svalbard Bank). Mar Biol 160:805-819

> Leu E, Mundy CJ, Assmy P, Campbell K and others (2015) Arctic spring awakening - steering principles behind the phenology of vernal ice algal blooms. Prog Oceanogr 139:151-170

> Lien VS, Gusdal Y, Vikebø FB (2014) Along-shelf hydrographic anomalies in the Nordic Seas (1960-2011): locally generated or advective signals? Ocean Dyn 64:1047-1059

> Loeng H, Ozhigin V, Aadlandsvik B (1997) Water fluxes through the Barents Sea. ICES J Mar Sci 54:310-317

Lyubin P, Anisimova NA, Manushin IE (2011) Long term effects on benthos of the use of bottom fishing gears. In: Jakobsen T, Ozhigin VK (eds) The Barents Sea. Ecosystem, resources, management. Half a century of RussianNorwegian cooperation. Tapir Academic Press, Trondheim, p 768-775

> Matrai P, Apollonio S (2013) New estimates of microalgae production based upon nitrate reductions under sea ice in Canadian shelf seas and the Canada Basin of the Arctic Ocean. Mar Biol 160:1297-1309

> McMahon KW, Ambrose WG Jr, Johnson BJ, Sun MY, Lopez GR, Clough LM, Carroll ML (2006) Benthic community response to ice algae and phytoplankton in $\mathrm{Ny}$ Ålesund, Svalbard. Mar Ecol Prog Ser 310:1-14

> Melle W, Skjoldal HR (1998) Reproduction and development of Calanus finmarchicus, C. glacialis and C. hyperboreus in the Barents Sea. Mar Ecol Prog Ser 169:211-228

Michalsen K, Dalpadado P, Eriksen E, Gjøsæter H and others (2013) Marine living resources of the Barents Sea-ecosystem understanding and monitoring in a climate change perspective. Mar Biol Res 9:932-947

Mueter FJ, Litzow MA (2008) Sea ice retreat alters the biogeography of the Bering Sea continental shelf each winter. Ecol Appl 18:309-320 
Mundy CJ, Gosselin M, Ehn J, Gratton Y and others (2009) Contribution of under-ice primary production to an iceedge upwelling phytoplankton bloom in the Canadian Beaufort Sea. Geophys Res Lett 36, L17601, doi:10.1029/ 2009GL038837

Nilsen M, Pedersen T, Nilssen EM (2006) Macrobenthic biomass, productivity $(P / B)$ and production in a highlatitude ecosystem, North Norway. Mar Ecol Prog Ser 321:67-77

Olli K, Wexels Riser C, Wassmann P, Ratkova T, Arashkevich E, Pasternak A (2002) Seasonal variation in vertical flux of biogenic matter in the marginal ice zone and the central Barents Sea. J Mar Syst 38:189-204

Orlova EL, Dalpadado P, Knutsen T, Nesterova VN, Prokopchuk IP (2011) Zooplankton. In: Jakobsen T, Ozhigin VK (eds) The Barents Sea. Ecosystem, resources, management. Half a century of Russian-Norwegian cooperation. Tapir Academic Press, Trondheim, p 91-119

Ozhigin VK, Ingvaldsen RB, Loeng $\mathrm{H}$, Boitsov V, Karsakov A (2011) Introduction to the Barents Sea. In: Jakobsen T, Ozhigin VK (eds) The Barents Sea. Ecosystem, resources, management. Half a century of Russian-Norwegian cooperation. Tapir Academic Press, Trondheim, p 768-775

Pearson TH, Rosenberg R (1978) Macrobenthic succession in relation to organic enrichment and pollution of the marine environment. Oceanogr Mar Biol Annu Rev 16: 229-311

Piepenburg D (2005) Recent research on Arctic benthos: common notions to be revised. Polar Biol 28:733-755

$>$ Piepenburg D, Blackburn TH, von Dorrien CF, Gutt J and others (1995) Partitioning of benthic community respiration in the Arctic (northwestern Barents Sea). Mar Ecol Prog Ser 118:199-213

Reigstad M, Wexels Riser C, Wassmann P, Ratkova T (2008) Vertical export of particulate organic carbon: attenuation, composition and loss rates in the northern Barents Sea. Deep-Sea Res II 55:2308-2319

Renaud PE, Riedel A, Michel C, Morata N, Gosselin M, Chiuchiolo A (2007) Seasonal variation in benthic community oxygen demand: a response to an ice algal bloom in the Beaufort Sea, Canadian Arctic? J Mar Syst 67:1-12

Renaud PE, Løkken TS, Jørgensen LL, Berge J, Johnson BJ (2015) Macroalgal detritus and food-web subsidies along an Arctic fjord depth-gradient. Front Mar Sci 2:31

Rosenberg R (1995) Benthic marine fauna structured by hydrodynamic processes and food availability. Neth J Sea Res 34:303-317

Roy V, Iken K, Archambault P (2014) Environmental drivers of the Canadian Arctic megabenthic communities. PLoS One 9:e100900

Editorial responsibility: James McClintock, Birmingham, Alabama, USA
Sakshaug E, Johnsen G, Kristiansen S, von Quillfeldt C, Rey F, Slagstad D, Thingstad F (2009) Phytoplankton and primary production. In: Sakshaug E, Johnsen G, Kovacs K (eds) Ecosystem Barents Sea. Tapir Academic Press, Trondheim, p 167-208

Slagstad D, McClimans TA (2005) Modeling the ecosystem dynamics of the Barents sea including the marginal ice zone: I. Physical and chemical oceanography. J Mar Syst 58:1-18

Slagstad D, Tande KS, Wassmann P (1999) Modelled carbon fluxes as validated by field data on the north Norwegian shelf during the productive period in 1994. Sarsia 84: 303-317

Slagstad D, Wassmann PFJ, Ellingsen I (2015) Physical constraints and productivity in the future Arctic Ocean. Front Mar Sci 2:85

Sun M, Carroll ML, Ambrose WG Jr, Clough LM, Zou L, Lopez GR (2007) Rapid consumption of phytoplankton and ice algae by Arctic soft-sediment benthic communities: evidence using natural and ${ }^{13} \mathrm{C}$-labeled food materials. J Mar Res 65:561-588

> Sundfjord A, Ellingsen I, Slagstad D, Svendsen H (2008) Vertical mixing in the marginal ice zone of the northern Barents Sea-results from numerical model experiments. Deep-Sea Res II 55:2154-2168

Tamelander T, Renaud PE, Hop H, Carroll ML, Ambrose WG Jr, Hobson KA (2006) Trophic relationships and pelagic-benthic coupling during summer in the Barents Sea Marginal Ice Zone, revealed by stable carbon and nitrogen isotope measurements. Mar Ecol Prog Ser 310:33-46

Vinogradova PS, Litvin VM (1960) Study of the topography and sediments in the Barents and Norwegian seas. In: Marty Y (ed) Soviet fisheries investigations in north European Seas. PINRO-VNIRO Press, Moscow, p 101-110 (in Russian)

- Wassmann P, Slagstad D, Wexels Riser C, Reigstad M (2006a) Modelling the ecosystem dynamics of the Barents Sea including the marginal ice zone II. Carbon flux and interannual variability. J Mar Syst 59:1-24

- Wassmann P, Reigstad M, Haug T, Rudels B and others (2006b) Food webs and carbon flux in the Barents Sea. Prog Oceanogr 71:232-287

- Wiedmann I, Reigstad M, Sundfjord A, Basedow S (2014) Potential drivers of sinking particle's size spectra and vertical flux of particulate organic carbon (POC): turbulence, phytoplankton, and zooplankton. J Geophys Res 119:6900-6917

Zenkevitch L (1963) Biology of the seas of the USSR. George Allen and Unwin, London

Submitted: August 28, 2015; Accepted: February 10, 2016 Proofs received from author(s): March 9, 2016 